Jurnal Matematika Ilmiah STKIP Muhammadiyah Kuningan

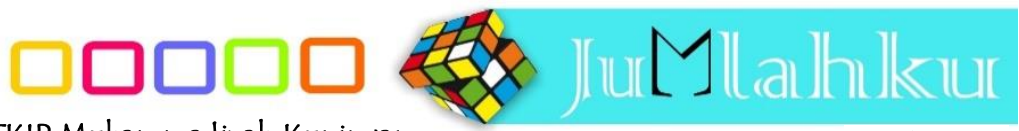
Vol. 5 No. 2 November 2019

\title{
Eksplorasi Unsur Matematika Dalam Pembuatan Batik Khas Tasikmalaya
}

Dedi Nurjamila), Elis Nurhayatib)

a,b) Program Studi Pendidikan Matematika, FKIP Universitas Siliwangi, dedi.nurjamil@unsil.ac.id

\section{Article Info \\ $\overline{K e y w o r d s ~: ~ e x p l o r a t i o n ~ o f ~}$ mathematical elements, Batik Tasikmalaya, geometry}

Submited: $2019-10-10$ Published: 12/4/2019

\begin{tabular}{l} 
Abstract \\
\hline This study aims to determine the mathematical content in making \\
batik typical of Tasikmalaya. This type of research is a qualitative \\
exploratory study. The subjects in this study were typical \\
Tasikmalaya batik artisans in the Cigereung area of Tasikmalaya \\
City. Data collection is done by means of data triangulation using the \\
method of interviews, observation and literature study. The results \\
showed that in terms of geometrical elements of Tasikmalaya batik \\
motifs, they have a relationship with the concept of transformation of \\
flat shapes, namely translation, reflection and rotation.
\end{tabular}


Kata Kunci: eksplorasi unsur matematika, Batik Tasikmalaya Geometri

\section{Abstrak}

Penelitian ini bertujuan untuk mengetahui kandungan matematika dalam pembuatan batik khas tasikmalaya. Jenis penelitian yang digunakan adalah penelitian eksploratif kualitatif. Subjek dalam penelitian ini adalah pengerajin batik khas tasikmalaya yang berada di daerah Cigereung Kota Tasikmalaya. Pengumpulan data dilakukan dengan cara triangulasi data yaitu menggunakan metode wawancara, observasi dan studi pustaka. Hasil penelitian menunjukan bahwa dari segi unsur geometri motif batik Tasikmalaya, memiliki hubungan dengan konsep transformasi bangun datar, yaitu translasi, refleksi dan rotasi. 


\section{PENDAHULUAN}

Matematika menjadi mata pelajaran yang wajib yang diberikan di setiap jenjang pendidikan mulai dari pendidikan dasar, menengah sampai dnegan perguruan tinggi. Tujuan mata pelajaran matematika diberikan salah satunya membekali siswa agar dapat berpikir logis, sistematis serta berpikir kreatif dan berpikir kritis. Banyak anggapan bahwa budaya terlepas dari unsur matematika. Padahal kalau kita kaji banyak budaya di Indonesia yang terdapat ide matematisnya. "Pendidikan dan budaya adalah sesuatu yang tidak bisa dihindari dalam kehidupan sehai-hari, karena budaya merupakan kesatuan yang utuh, menyeluruh, dan berlaku dalam suatu masyarakat, serta pendidikan merupakan kebutuhan mendasar bagi setiap individu dalam masyarakat" (Budiarto, 2016, p.2).

Berdasrakan pengertian tersebut bahwa pendidikan dan budaya dalam konteks masyarakat tidak dapat dipisahkan antara satu dengan yang lainnya dengan demikian dapat dikatakan bahwa budaya merupakan perwujudan dari hasil pendidikan dan keduanya saling melengkapi.

Kajian mengenai matematika sebagai budaya dalam hal ini dikenal dengan etnomatematika menjadi trending di kalangan peneliti matematika itu sendiri. Etnomathematics dalam bahasa Indonesia dikenal dengan istilah etnomatematika.
Etnomatematika merupakan studi tentnag ide-ide matematika dari masyarakat tradisional (Ascher, 1991). "Sehingga matematika merupakan bagian dari budaya dan sejarah" (Fathani, 2009, p.87). Berdasarkan pendapat tersebut maka banyak unsur dari budaya yang masuk dalam ide matematis. Salah satunya adalah ide matematis dalam pembuatan kain batik. Istilah etnomtatemtaika mulai populer setelah dikenalkan oleh D'Ambrosio pada tahun 1977. D'Ambrosio (1985, p.45) yang menyatakan bahwa etnomatematika merupakan matematika yang digunakan dalam kelompok-kelompok budaya yang dapat diidentifikasi. Etnomatematika dapat dipahami sebagai suatu bidang ilmu yang mempelajari hubungan antara matematika dan budaya.

Perkembangan etnomatik telah menjadi perbincangan hangat dalam pembelajaran matematika di sekolah. Rosa dan Orey (2011) melakukan riset tentang ethomatematics. Tujuan dari riset mereka adalah bagaimana pembalajaran matematika di sekolah lebih mempertimbangan latar belakang sosiokultural peserta didiknya.

Hasil penelitiannya menunjukkan bahwa ternyata pembelajaran menggunakan pendekatan sosiokultural membantu peserta didik mengembangkan intelektual, pembelajaran sosial, emosional, dengan menggunakan acuan budaya mereka sendiri yang unik yang

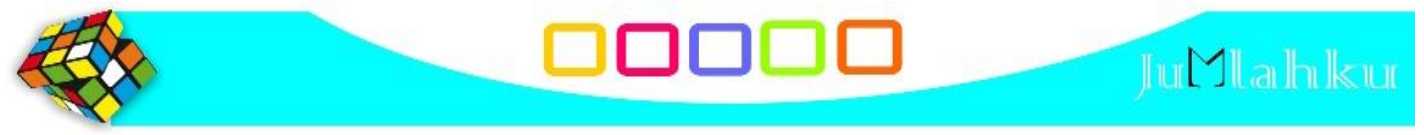


menghasilkan

pengetahuan,

keterampilan, dan sikap yang lebih baik. Hasil penelitian tersebut mendasari kedudukan etnomatematika penting dalam konteks pembelajaran.

Dengan pembelajaran berbasis etnomatematika selain dapat mempelajari matematika secara kontekstual siswa juga dapat memahami budaya dan dapat menumbuhkan nilai karakter (Shirley, 2001). Nilai karakter yang dimaksud adalah karakter kecintaan siswa terhadap budaya di daerah tersebut. Budaya tersebut tentu memberikan rasa cinta yang tinggi terhadap kecintannya terhadap daerah tersebut. Adam (2004) adalah dengan memanfaatkan pendekatan ethnomathematics sebagai awal dari pengajaran matematika formal yang sesuai dengan tingkat perkembangan mahasiswa yang berada pada tahapan operasional konkret.

Batik merupakan ciri khas dari bangsa Indonesia yang diakui dunia. Berbagai unsur matematika terdapat dalam motif batik yang di buat oleh seorang perajin batik. Batik memiliki khasan karena memiliki pola yang erat kaitannya dengan transformasi bangun datar dalam konteks matematika hari ini. Hal ini digambarkan pada contoh motif pakian khas suatu suku sebagai berikut:
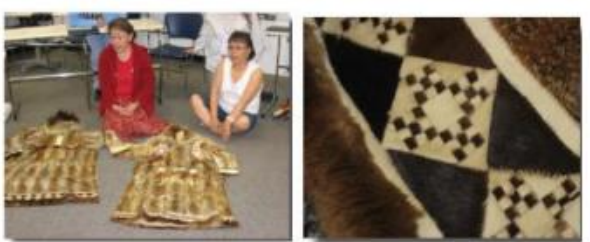

Gambar 1. Motif Pakaian Budaya Yup'ik Dora Sumber: Lipka dan Andrew-Irkhe, (2009, p.8)

Terlihat bahwa motif pakaian tersebut memiliki ide matematis yang cukup menarik. Mulai dari teori kesebangunan sampai dengan transformasi bangun datar dalam hal ini refleksi atau pencerminan. Batik Tasikmalaya merupakan batik yang memiliki kekhasan dalam batik nusantara. Batik Tasikmalaya memiliki motif yang beragam, untuk mencari batik Tasikmalaya ada satu daerah yang terkenal dengan batiknya yaitu Cigereung. Di setiap sudut jalan cihideun anda akan melihat pemandangan mengenai batik khas Tasikmalaya. Motif batik tasikmalaya mempunyai tiga motif batik populer yaitu motif batik burung, motif batik payung, dan motif batik kacang panjang yang sangat kental dengan nuansa kota parahyangan. Beberapa motif pengembangan dari batik tasikmalaya yang lain seperti batik bunga anggrek dengan isen-isen burung, motif batik merak ngibing, motif batik cala culu, motif batik pisang bali, motif batik sapu jagat, dan motif batik awi ngarambat juga ada beberapa motif

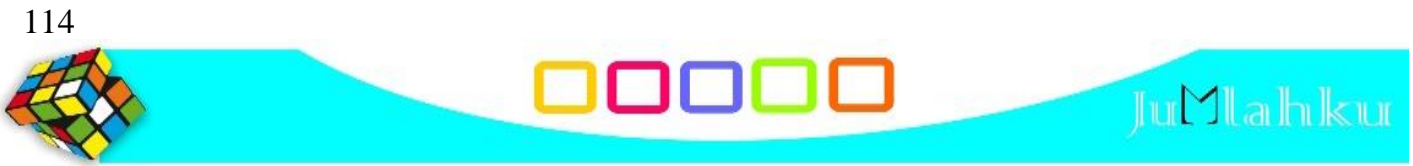


turunannya yang bermotif seperti akar, balimbing, antanan, guci latar batu, lancah tasik, rereng daun peuteuy papangkah, sente, tsunami udey, merak, gunung kawi, lamban samping, kadaka, lancah sawat ungu, renfiel, rereng orlet, rereng sintung, manuk latar sisik, manuk rereng peutey selong, merak latar haremis, sidomukti payung, taleus sukaraja, sisit naga, dan turih-wajit-Limar

(sumber: https://batik tulis.com/blog/batik-tasikmalaya/).

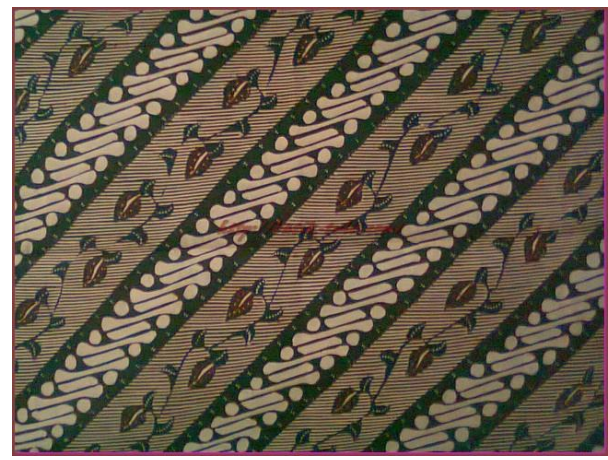

Gambar 2. Motif Batik Tasikmalaya

bahwa motif batik Tasikmalaya memiliki kehasan dan jika kita lihat memiliki ide matematis geometeri terutama mengenai ide transformasi yang memiliki pergeseran yang sistematis. Berdasarkan uraian dari latar belakang masalah tersebut peneliti tertarik untuk mengeksplor lebih jauh lagi mengenai jenis-jenis batik di Tasikmalaya yang kemudian dihubungkan dengan ide matematis pada konsep matematika. Ketertarikan tersebut dibuat dalam sebuah judul "Eksplorasi Unsur Matematika Dalam Pembuatan Batik Khas Tasikmalaya", Berdasarkan uraian masalah yang dikemukakan maka tujuan dari penelitian ini adalah untuk mengetahui eksplorasi unsur matematika dalam pembuatan batik khas tasikmalaya

\section{METODE}

Penelitian ini merupakan jenis penelitian eksploratif kualitatif. Arikunto (2006, p.7) menjelaskam "penelitian eskploratif merupankan penelitian yang bertujuan untuk menggali secara luas tentang sebab-sebab atau hal-hal yang mempengaruhi terjadinya sesuatu", Kemudian Sugiyono (2007, p.49) menyatakan "dalam penelitian kualitatif tidak menggunakan istilah populasi tetapi oleh spradley dalam Sugiyono (2007:49) dinamakan social situation atau situasi soaial yang terdiri dari tiga elemen yaitu: tempat, pelaku dan aktifitas. Pada situasi sosial atau obyek penelitian ini penelitian dapat mengamati secara mendalam aktivitas orang-orang yang ada pada tempat tertentu". Oleh karena itu, pada penelitian ini mengungkap bagaimana ide matematis diungkap dalam motif batik khas Tasikmalaya. Penelitian ini dilaksanakan di perajin batik Tasikmalaya di Cigereung Kota Tasikmalaya. Yang menjadi fokus dalam penelitian ini adalah motif yang disajikan yang kemudian dihubungkan dengan ide matematis pada batik tersebut

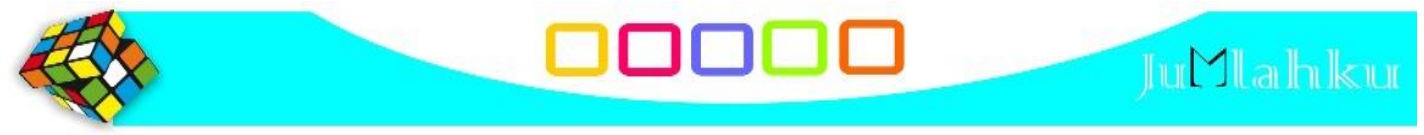




\section{HASIL DAN PEMBAHASAN}

Pelaksanaan penelitian dengan judul "Eksplorasi Unsur Matematika Dalam Pembuatan Batik Khas Tasikmalaya" penelitian dilaksanakan selama 5 kali dengan mengunjungi pengerajin Batik Khas Tasikmalaya. Pengerajin yang dikunjangi berada di sekitaran daerah Cigereung. Kemudian untuk sejarah Batik Tasikmalaya dilakukan observasi dan wawancara di Koperasi Mitrabatik Tasikmalaya. Penelitian ini dibantu dua mahasiswa yaitu saudara Hendri Maulana dan Hesti Novianti. Batik tulis mulai dikenal oleh masyarakat Tasikmalaya pada masa Kerajaan Tarumanegara. Hal tersebut diperkuat dengan jumlah populasi pohon tarum yang cukup banyak guna pembuatan batik pada masa itu. Wilayah Mangunreja, Sukapura, Maronjaya, Wurug, dan Tasikmalaya Kota terdapat jejak sejarah batik tasikmalaya karena memang merupakan area pemerintahan tarumanegara yang berpusat di Sukapura yang berada di pinggiran kota Tasikmalaya. Asal mula batik tasikmalaya adalah gelombang pengungsian penduduk dari wilayah jawa tengah karena terjadinya perang di wilayah tersebut hingga pada akhirnya budaya membatik dibawa sampai sekarang.

Eksplorasi unsur matematika di lakukan berdasarkan proses analisis yang dilakukan oleh peneliti dipandu dengan ahli semiotika batik. Berdasarkan wawancara dengan $\mathrm{H}$. Cacu pemilik Batik Agnesa bahwa untuk membuat batik dapat dilakukan dengan berbagai cara diantaranya:

1. Batik Canting Tulis/Batik Tulis, batik tulis merupakan batik yang dibuatnya secara manual dan hanya menggunakan canting, malam, serta tangan untuk membuat motifmotifnya.

2. Batik Cap, merupakan batik yang pembuatanya menggunakan canting yang berbentuk khusus dan timbul sehingga tinggal dicapkan ke kain mori.

3. Batik Celup Ikat, merupakan batik yang pembuatannya diikat kemudian dicelupkan ke beberapa variasi warna sehingga menghasilkan batik yang berwarna warni.

4. Batik Printing, merupakan batik yang pembuatanya menggunakan mesin modern dan pewarnaanya tidak menggunakan malam.

5. Batik Colet, merupakan batik yang pembuatannya dengan cara dilukis, biasanya batik ini dilukis dengan kuas, kapas, dan canting

Proses observasi dilakukan langsung di tempat pembuatan batik Khas Tasikmalaya.

\section{6}




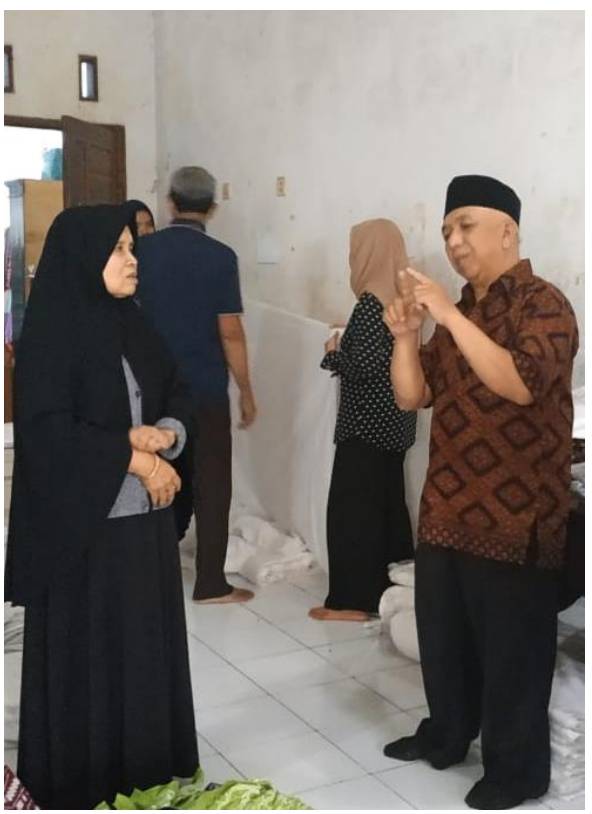

Gambar 5. Observasi dan wawancara dengan pemilik Batik

Berdasarkan hasil wawancara yang dilakukan oleh peneliti bahwa untuk membuat batik tulis memerlukan waktu sekitar 2-3 hari. Batik tulis memiliki nilai jual yang cukup tinggi sehingga harganya bisa mencapai 2-3 juta, karena prosesnya lama menggunakan tangan meskipun sebelumnya dilakukan penggambaran di kain yang sudah disedikan, sehingga pembatik tinggal meneruskan hasil dari gambar yang sudah disedikan. Meskpiun demikian perlu kehati-hatian dikarenakan jika salah terhadap motif akan sulit untuk membetulkannya lagi. Selain kepada pemiliki Batik, peneliti juga melakukan wawancara kepada pembatiknya langsung. Berikut proses nya:

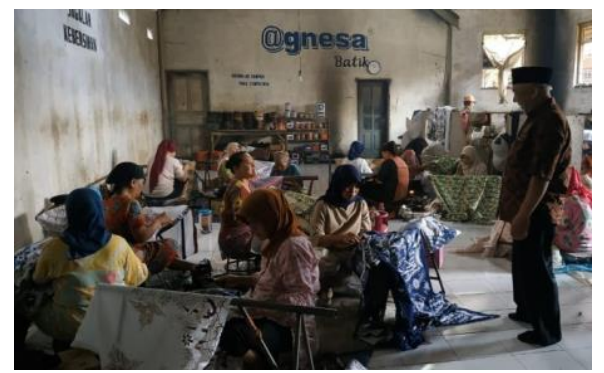

Gambar 6 Observasi dan wawancara dengan Pembatik

Berdasrakan hasil wawancara dengan pembatik didapatkan bahwa mereka tidak menyadari bahwa motif batik yang dibuat ada kaitannya dengan matematika. Mereka hanya menggambar motif sesuai dengan gambar yang disedikan tanpa berpikir bahwa motif tersebut ada kaitannya dengan matematika. Artinya bahwa pembatik meskipun tidak memahami kaitan motif dengan matematika tetapi ada budaya dalam melakukan proses pembuatan batik tersebut. Beberapa yang didapat oleh penulis mengenai motif batik khas Tasikmalaya adalah sebagai berikut:

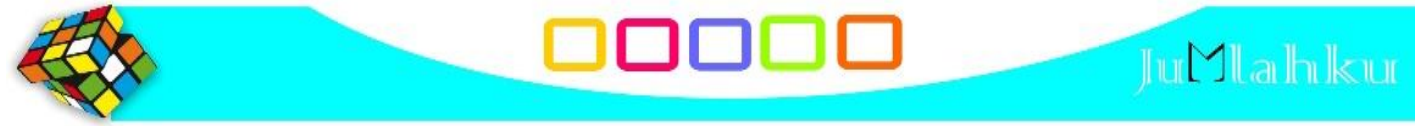




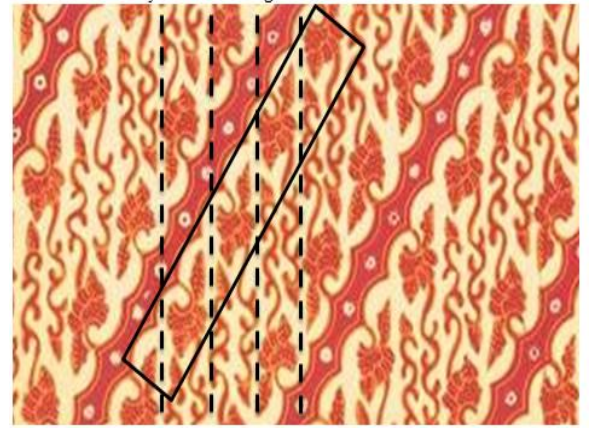

Gambar 7. Batik Sawoan, Motif Buah Sawo Coklat

Apabila kita amati dengan jelas dan mendalam maka motif ini memiliki kaitan dengan konsep matematika yaitu mengenai transformasi bangun datar yaitu pada materi translasi. Secara sederehana transalasi dapat dikatakan sebagai pergeseran, jika kita lihat batik tersebut maka memiliki pergeseran yang sistematis yaitu berpindah ke sebelah kanan dengan sistematis.

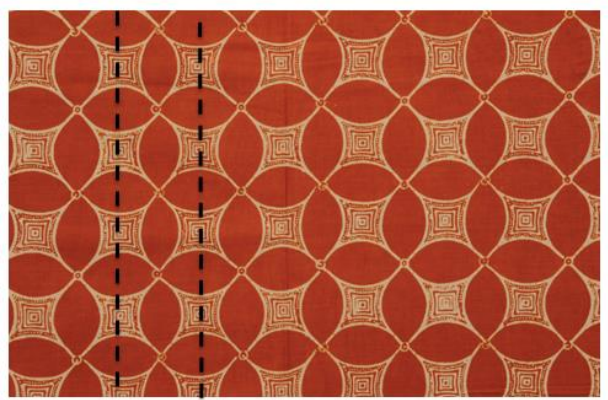

Gambar 8. Batik Motif Kawung

Motif batik ini juga apablia secara mendetail kita lihat maka kita akan melihat bahwa motif ini memiliki ide matematis yaitu mengenai refleksi atau pencerminan. Refleksi yang dimaksud adalah refleksi terhadap sumbu y. Pada motif kawung juga terlihat berkaitan dengan rotasi. Rotasi atau perputaran akan kembali padda titik semulanya.

\section{PENUTUP}

\section{Simpulan}

Melalui penelitian mengenai eksplorasi unsur matematika pada pembuatan motif batik khas Tasikmalaya didapatkan suatu kesimpulan bahwa beberapa motif batik khas Tasikmalaya memiliki ide geometris yang berkaitan dengan transformasi bangun datar. Batik sawon dan batik motif kawung memiliki kaitan dengan unsur transformasi bangun datar yaitu translasi, refleksi dan rotasi.

\section{Saran}

Sebagai bagian dari budaya Indonesia yang telah disyahkan. Batik merupakan khas dari Indonesia. Melalui penelitian ini diharapkan orang mengenal bahwa matematika ternyata ada pada unsur budaya salahsatunya motif batik, sehingga orang yang memakai batik dengan motif tertentu memiliki keterkaitan dengan salah satu konsep matematika.

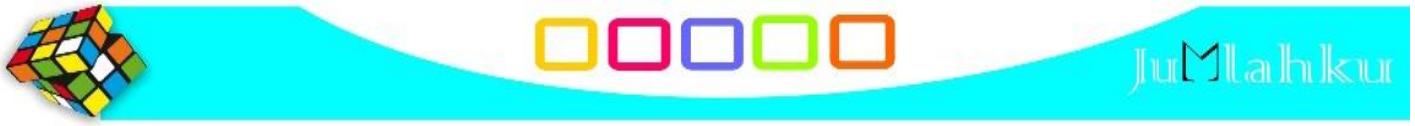




\section{DAFTAR PUSTAKA}

Adam, S. 2004. Ethnomatematical Ideas In The Curriculum. Mathematics Education Journal. 16(2), 49-68.

Arwanto. (2017). Eksplorasi Etnomatematika Batik Trusmi Cirebon Untuk Mengungkap Nilai Filosofi Dan Konsep Matematis. Jurnal Pendidikan MIPA Phenomenon. Vol. 1 No. 12017

Ascher, M,. (1991). Ethnomathematics: A Multicultural view of mathematical ideas. Pasific Grove. Calivornia

Budiarto, Mega Teguh. (2016). Peran Matematika dan Pembelajarannya Dalam Mengembangkan Kearifan Budaya Lokal Mendukung Pendidikan Karakter Bangsa. Prosiding Seminar Nasional 2016 Program Studi Pendidikan Matematika Universitas Madura, Madura. Hal. 1-11

D'Ambrosio, Ubiratan. (1985). Ethnomathematics and its Place in the History and Pedagogy of Mathematics, For the Learning of Mathematics, 5(1) 44-48

Fathani, A. H. (2009). Matematika Hakikat \& Logika. Jakarta: Ar-Ruzz.

Lipka, Jerry dan Andrew-Irkhe, Dora. (2009). Ethnomathematics Applied to Classroom in Alaska: Math in a Cultural Context. Paper at the
NASGEM Ethnomathematics SIG at the 2009 Annual Meeting NCSM. $p$. 8-10

Rosa, Milton dan Daniel Clark Orey. (2011). Ethnomathematics: the cultural aspects of mathematics. Revista Latinoamericana de Etnomatemática, 4(2). 32-54

Shirley, L. (2001). Ethnomathematics as a fundamental of instructional methodology. ZDM, 33(3).

Shirley, L. 2008. Looks Back Ethnomathematics and Look Forward. Journal International Congress of Mathematics Education. 6. 6-13.

Sirate, F. (2012). Implementasi etnomatematika dalam pembelajaran matematika pada jenjang pendidikan sekolah dasar. Lentera Pendidikan, 15(1), 41-54.

Windria, H. (2016). Batik Kaya Matematika, Memanfaatkan Motif Batik dalam Kelas Matematika. In Prosiding Seminar Nasional Pendidikan Matematika 2016 Universitas Kanjuruhan Malang. Malang

Zayyadi, M. (2017). Eksplorasi Etnomatematika pada Batik Madura. Jurnal Sigma 2(2), 36-40.

https://batik-tulis.com/blog/batiktasikmalaya/ 